\title{
Citizen Participation: A Matter of Competency
}

\section{Sassi Boudemagh Souad}

Constantine 03 University, Architecture and Urbanism Institut, Algeria

Korti Rafika

Constantine 03 University, Architecture and Urbanism Institut, Algeria

\begin{abstract}
Citizens are social actors willing to give their time and energy to participate in collective projects, in order to live better in their built environment. Thus, the inhabitant is not only apprehended as a figure of belonging to a place, but he is perceived as being able to act on his environment, to be in connection with it. He is the one who invents his living environment and, beyond, transforms the city in the same way as the other actors. Individuals must acquire skills to become effective participatory citizens and live together in peace and on an equal footing in democratic societies. The recent work in the social sciences, which deals with "scholarly knowledge" and "ordinary knowledge", makes it possible to conclude on this notion of skills and to make the link with the question of the participation of the inhabitants. The "scholarly knowledge" is classified as scientific academic and professional knowledge, opposing knowledges qualified as profane or ordinary, that is to say, shared "by all or part of the social world". From a systemic point of view, the process of participation would be the meeting of these academic knowledge and lay knowledge. The purpose of this article is to understand what types of skills the resident uses, as a resource person, a living force, to engage in the process of participation.
\end{abstract}

Keywords: the citizen, citizen participation, skills, scholarly knowledge and ordinary knowledge.

\section{Introduction}

The Council of Europe publications on the project "Education for Democratic Citizenship" (Council of Europe, 1997) gave different definitions of participation, including: 
Participation is a "power based on the possibility of influencing the social and economic aspects of life in the wider community" (Golubovic, 1982, cited in Council of Europe, 1997, p.13).

In another 1990 European publication, participation is defined as "the right of young people to be included, allowed and encouraged to assume duties and responsibilities and to take decisions that affect them" (Council of Europe, 1997, p.13).

On the other hand, the participation process is part of a logic of solidarity, where human, democratic and citizen values take shape in the identity construction of an actor. From this process arise attitudes, skills, knowledge, that enable the inhabitant "as a main actor in the process of participation" to act in an effective way.

Understanding the parameters of "citizen participation" requires matching their "knowledge", value systems and skills.

This is a current notion that occupies an important place in pragmatic sociology. Indeed, the emergence of skills is studied in the theoretical field of public policies, around the notion of "capacitation".

This notion refers to the human, social and technical capacities. As long as it is a question of designating, the relation that the actor maintains to the acts that he poses. So, do inhabitant have particular skills promoting their participatory process?

This research work is mainly inspired by Council of Europe publications on the project "Education for democratic citizenship" and the studies of Guy Le Boterf

\section{The concept of competency}

The competency of a person in an area of expertise are relevant past experiences that may influence a person's will to participate in an organization, project or take a particular role.

This concept is studied in different fields, namely, human resources, anthropology, social sciences, pragmatic sociology and sociology of work...

The term "competence" is used in many ways, including in ordinary language as a synonym for "aptitude" or, more technically, as part of the education and professional training, or to refer to the ability to meet complex requirements in a given context.

The long-standing Council of Europe in the fields of education for democratic citizenship and intercultural dialogue has defined competence through the ability to mobilize and use values, attitudes, skills, knowledge and skills or relevant understanding in order to respond effectively and appropriately to the demands, challenges and opportunities that arise in democratic and intercultural situations. Competence is treated as a dynamic process in which an individual mobilizes and 
uses a set of psychological resources in an active and flexible way to respond to unexpected situations.

The educational sciences define this concept as follows: A competency is an integrated set of capabilities that allows one to spontaneously grasp a situation and respond to it in the most appropriate way possible.

Guy le Boterf proposes another definition: "Competence is the mobilization or activation of several knowledge in a given situation and context". (...) The Competences are mainly exercised in professional or social life or in leisure. (...) Finally, Competences are the culmination of knowledge.

\section{The dimensions of Competences}

From the studies of Guy Le Boterf, we can analyze this notion by breaking it down into three aspects of knowledge: knowledge, know-how and know-how to be or attitude. In the same way, these three categories of knowledge are exerted in three domains specific to the social being, they are: the cognitive domain, psychomotor domain and socio affective domain. However these three knowledge are linked. Because it is the concomitance of these three elements that creates a particular "dynamic". These aspects of knowledge are therefore all three necessary for the accomplishment of urban projects where the process of the participation of inhabitants is inscribed.

Knowledge, know-how and know-how to be are the resources that a person can mobilize in the action in order to prove his competence. These are complementary resources referring to different dimensions of the competency:

\section{Knowledge (cognitive competences)}

Every human being has knowledge. This is the body of knowledge acquired through learning (studies) or experience. This knowledge tends to be enriched, but it can also be degraded, and it has especially the precious quality of being usable and communicable.

It can be said that knowledge is a source of power and enrichment for its holder. Knowledge gains full value only when it leads to action.

Knowledge is a foundation of knowledge, called theoretical, which is constructed and evolves according to personal history. It is always personal, articulated according to the history of the subject but also with the cultural and social context of the latter. The relation to knowledge can be defined as a process by which a subject, based on acquired knowledge, produces new singular knowledge enabling him to think, to transform and to feel the world. 
Drucker sees knowledge as the only resource that has meaning in the perspective of the new economy, which is mainly characterized by the dematerialization of trade and production (from the book "Post-capitalist society", 1993).

Grant states that knowledge is information and know-how, held by individuals and not by organizations, and is the most important resource of the company (from the book "Toward a knowledge-based theory of the firm ", 1996).

He refers to theoretical or declarative knowledge: it is the mastery of vocabulary, norms and laws, data and characteristics on products, tools or services ... By knowledge, we mean all the information that a person possesses and which are indispensable for effective participation:

\section{Knowledge of communication}

This is knowledge of:

The fact that people who have other cultural references may follow verbal and nonverbal communication conventions that are different from their own, important from their point of view, even if they use the same language;

The social impact and impact on others of different communication styles, including how different communication styles may be incompatible or result in a break in communication;

The fact that there are multiple ways to speak in a given language and multiple ways to use the same language. Different communication tools and their dissemination methods.

\section{Knowledge of politics and law}

It encompasses knowledge of:

Basic political and legal concepts related to participatory democracy, such as democracy, freedom, justice, equality, citizenship, rights and duties, the need for laws and regulations, and the state of law ;

Democratic processes and the functioning of political institutions, including the role of political parties;

Various ways in which citizens can participate in public debate and decision-making, and influence politics and society, including the role that civil society and NGOs can play in this regard.

\section{Knowledge of human rights}

That is knowledge of:

- the fact that human rights are based on the inherent dignity of all human beings; 
- the fact that human rights are universal, inalienable and indivisible, and that while human rights are recognized for every human being, everyone must respect the rights of others, regardless of their national origin, ethnicity, race, religion, language, age, sex, gender, political opinion, birth, social origin, wealth, disability, sexual orientation or any other situation;

States and governments' human rights obligations.

\section{Know-how (practical competence)}

The know-how corresponds to the control of the operating modes and processes. This knowledge concerns the mastery of one or more techniques essential to the practice of a craft or an art. We can extend our know-how to other areas of our private life, to highlight our talents. The know-how is not acquired forever, it is constantly rehabilitated and updated by the experiences, whether professional, voluntary or personal.

It is defined as a skill to implement one's experience and knowledge acquired in any art or craft. This combination of two infinitives, Know and do, combines knowledge and action, and comes from field experience.

Professor J.M. Mousseron gave another definition of know-how: "technical knowledge, transmissible, not immediately accessible to the public and not patented, and for which someone would be willing to pay to know it".

Jean Verré (1997) recognizes the usefulness of introducing the notion of aptitude. He justifies the psychological dimension of studies and admits that the experience (know-how) is changing at varying rates, depending on the skills and individual characteristics. Verré speaks of ability, defined in part by "the natural or acquired disposition of someone 'one to do something' and on the other hand, by the psychological sense 'dimension according to which the individuals are differentiated » (Verré 1997).

We also defend the idea that aptitude is only a potential to activate to become a skill. In this, we reach Aubret who, from the definition of the aptitude, releases restrictive factors and affirms that the aptitudes are considered like cognitive characteristics responsible for the acquisition and the treatment of the information (Aubret, Gilbert et al., 1993). Moreover, they point out that the concept of aptitude is not an observable but a cognitive construct.

In psychology, the word aptitude refers to the psychological characteristics that make it possible to predict interindividual differences in future learning situations. The concept originates from the Latin word aptus, which means "capable of".

We must distinguish between the use of the term in colloquial language and that of psychology. In the common language, aptitude refers to the ability of a person to perform a task / activity correctly. In psychology, contrariwise, the term includes 
both the cognitive abilities that emotional characteristics and personality. That said, aptitude is associated with intelligence and natural dispositions or those acquired through a learning process.

It is the ability to perform complex and organized modes of thought or behavior by adapting evidence to reach a goal or a particular purpose.

Abilities come from a wide variety of skill abilities that, in turn, have a link to several logical andmathematical abilities for effective citizen participation, ability can belong to listening and observation, to understanding verbal and written expression, communication and cooperation, conflict resolution...Etc.

\section{Ability to listen and observe}

These are the skills needed to understand what others are saying and to learn from their behavior. Understanding what others say requires active listening - paying careful attention not only to the content of the words but also to the way they are expressed by the tone, timbre, loudness, flow, and fluidity of the voice. As well as the body language of the person, especially eye movements, facial expressions and gestures. Careful observation of the behavior of others can also be an important source of information about the behaviors that are most appropriate and effective in various social and cultural contexts, and can help the learner to control these behaviors by retaining this information, and reproducing this behavior in later situations of the same type.Therefore, listening and observation include the capacity or ability:

- to pay attention not only to the content of the words but also to the way they are expressed, as well as to the body language of the author of the words;

- to pay attention to possible inconsistencies between verbal and non-verbal messages;

- to pay attention to the subtleties of meaning and to what can only be partially said, or indeed what is implicit;

- to be very attentive to the behavior of others and to retain information about this behavior, in particular the behavior of people perceived as having cultural references different from their own;

- to be very attentive to the similarities and differences in the way people react to the same situation, especially those perceived as having cultural references different from their own.

\section{Capacity for cooperation}

Cooperation within a group is of a social nature. It can be covered by individual evaluation or even by observation of social interactions. Individuals have very 
different social skills, which should have decisive effects on their relationships and their mode of cooperation in larger groups, when they are implemented on others.

To work in a group, it is necessary to understand the changing nature and purpose of the standards and rules, and have practical experience. These are the skills necessary to participate fully, with others, in common activities, tasks and projects; it is also about taking action jointly with other people.

\section{Ability to resolve conflicts}

These are the skills required to process, manage and peacefully resolve conflicts, namely, in particular, the ability or capacity:

- to mitigate or prevent aggression and negativity, and to create a neutral environment in which people feel free to express their differing opinions and concerns without fear of reprisal;

- to encourage and enhance receptivity, mutual understanding and trust between the parties to the conflict;

- to recognize the inequalities of power and / or status between the parties to the conflict, and to take steps to reduce the possible effects of these inequalities on communications between these parties;

- to hear and understand the points of view of the various parties involved in the conflict;

- to help others resolve conflicts by helping them understand the options available to them;

- to assist and guide the parties concerned to agree on an optimal and acceptable solution to the conflict.

- Communication, but also team problem solving are central aspects of human behavior that can only be studied through observation (Gottman 1994, Vuchinich, Vuchinich\& Wood, 1993).

\section{The know how to be (moral competences)}

The know how to be translates the opinions, attitudes and behaviors of the person.

The know how to be manifests what the person is basically, that is to say, his human qualities. It belongs to our social knowledge related to our representations, to our ability to communicate.This knowledge manifests the way of apprehending one's own person, the others, the environment, situations and life in general; he thus determines his way of acting and reacting. It is the way to behave in public, to react to changes, to deal with a new situation. 
This notion is used interchangeably as equivalent to "behavioral skills" or "behavioral knowledge". Similarly, the decomposition of attitudes shows that the notion can also cover "attitudes".

The human being is inserted from birth into social relationships with his community. He speaks, he makes contacts, he reads, writes, etc. Thus, Damon (1998), in a panorama of studies on political development, found that the history of inter- human relationships of a person is a backdrop for its democratic behavior within society. So «A person's ability to act as a civilian member of a community is always at the heart of democratic political engagemen, and the genesis of this ability can be traced throughout the history of the person's interpersonal relationships. "

He considers the moral identity of a person as playing an important role in the exercise of his participative skills and in his social attitudes. "Moral identity is an essential component of political development because it is needed to turn judgment into action. Moral identity provides a powerful incentive for driving because it engenders a sense of responsibility to act in accordance with one's self-concept. "

But unfortunately the theoretical hypotheses of Damon (1998) are not experimental because one can not know the complete history of the reports of the people and their "moral identity" is not directly measurable.

Indicators should therefore be defined, describing the aspects of personality and moral identity, which are capable of constituting factors encouraging participation in a democratic society.

After several researches, we extracted traits that reflect the moral skills of a person, they were presented by Damon (1998) and the project of the Council of Europe, we grouped them in two sub-dimensions: value and attitude

\section{Values}

Value is a fundamental notion in public life. According to several authors (Tocqueville, Weber, Durkeim). They are at the origin of the laws, rules, conventions and customs that govern the groups and the relations between the individuals that compose them (Brée, 1994). They are used to characterize individuals or societies, to track change over time, and to explain the basic motivations behind attitudes and behaviors.

They have been a very important subject of research in many fields of study, sociology, psychology, anthropology and all related disciplines.

They have thus seen different definitions, such as: "Sustained belief that a specific mode of conduct or purpose of existence is personally and socially preferable to other behaviors or goals" (Rokeach, 1968). But also, "collective preferences that appear in an institutional context and participate in its regulation" (Boudon and Bourricaud, 1983); "Adherence of individuals to goals that satisfy interests in motivational domains and of greater or lesser importance in everyday life" (Schwartz and Bilsky, 
1987); "What men value, like, desire, recommend, even propose as ideal" (Rezsohazy, 2006).

"Value": idea or conceptual reference (which can be embodied in a person) that guides or directs our judgments and actions. Talk about principle rather than value? Yes, in the sense that the value means conviction, opinion, attachment, subjective preference, individual or collective, that the individuals would share in more or less number, that they could one day accept, another refuse, simple beliefs neither respectable nor not respectable, simply factual and subject to infinite discussion.

Values are needed to explain organization and change, at the level of society as well as of individuals.

When we think of our values, we think about what we think is important in life. Each of us assigns various degrees of importance to many values (success, security, benevolence). What distinguishes one value from another is the type of purpose or motivation that this value expresses; we do not have the same values.

According to our field, we have chosen the values related to participation that must be mobilized and used to respond to the demands and challenges of democratic situations, they are essential to conceptualize the skills to participate in a culture of democracy.

As a result, the values defined in our model lie at the very heart of the democratic competence and are essential to describe this competency.

\section{Values : valuing democracy: equality and freedom:}

This set of values is based on a group of beliefs about how societies should function and be governed. Notably, that among others, that all citizens should participate actively in the democratic procedures in force in their society, social justice, equity and equality should exist at all levels of society and that the rule of law should prevail, so that all members of society are treated fairly, equitably, impartially and equally, in accordance with the laws applicable to all.

We will not return to the controversies surrounding the question of the universality of values and admit that some of them are unavoidable when we speak of a participative and pluralistic democracy: justice, freedom and solidarity. Each of these values refers to others that extend them back; justice implies equality, freedom implies responsibility, and solidarity leads to commitment.

\section{Equality}

Equality is undoubtedly the founding and structuring value of democracy. This principle of equality is a fundamental rule of law that the community institutes and applies in all its decisions without any question of challenging it in the name of other ideas or values or beliefs. 
It is a principle of the political reason according to which we declare, we affirm, we want that all men are equal in rights, abstracting from the accidental differences which characterize them (kind, origin, social environment, religion ...) and which do not do not touch their human essence.

It is about organizing the allocation of power so that all citizens have an equal opportunity to obtain it, to exercise this power, without some of them being privileged and others excluded.

It is a sense of social justice and social responsibility to ensure that all members of society enjoy fair and equitable treatment, including equal opportunities for all, regardless of national origin, ethnic origin, race, religion, language, age, sex, gender, political opinion, birth, social origin, fortune, disability, sexual orientation or any other situation.

\section{Freedom}

In the sense of not depending on an external and transcendent authority that would force us to follow certain rules of life and to target certain goods without being able to judge, to decide, to refuse. Freedom, in the sense of independence of the individual who intends to be the author of his existence in a community that protects him without submitting to him, to develop his capacities, to exercise his talents, to benefit from the fruits of his labor in a sense and under conditions that he will have the right to judge alone.

It is about taking part, participating in the exercise of common power. Being an active citizen in its own right, who participates in the elaboration of the law to which he is supposed to obey: "The obedience to the law that is prescribed is freedom" (Rousseau). Aristotle (Politics, VI, 2) was, in a more radical sense, indicating that democratic freedom consists of the citizen being alternately governed and governing, capable today of governing those to whom he will be able to obey tomorrow.Essence of the democratic logic: to be free is to participate in the exercise of the common power in order to be free even in the obedience to the law, to have no master except the law that one wanted oneself either way.

In addition, more generally, the promotion of freedom is the recognition of the need to protect individual freedoms, especially people whose point of view is a minority.

Associative membership is still a good indicator of the democratic vitality of a society. Interlocated between the individual and the state, voluntary associations are localized democratic bodies, promoting the cohesion of society.

\section{Attitudes}

The American psychologist Gordon Allport defined the notion of attitude as " $a$ mental and neuropsychological state of preparation for action, organized after the 
experiment, which concerns a dynamic influence on the behavior of the individual with regard to all the objects, and all the situations related to it».

Attitude is the "state of mind" of a subject or group vis-à-vis an object, an action, another individual or group. It comes out of someone's skill. It is a mental predisposition to act in one way or another. Above all, it refers to an intention and is therefore not directly observable. It is an indispensable concept in the explanation of social behavior and a necessary notion in the explanation of reactions to a task.

It is a hypothetical construct that represents the degree of resemblance or dislike of an individual for an object. Attitudes are generally viewed as a kind of disposition to various aspects of the world, including people, events and subjects.

For Thomas and Znaniecki, an attitude is always oriented towards an object. It can predict the actual and potential behaviors of an individual in the face of social stimulation. As the social objects in relation to which individuals are called to be situated are collective values, the attitude is defined by these authors as "a state of mind of the individual towards a value". This idea of a necessary connection between attitude and value is taken up by Park. But the latter specifies the definition by adding a number of properties : an attitude varies in intensity ; it is based on experience. The first property therefore indicates that an attitude is susceptible of degrees. The second is introduced essentially to distinguish the notion of attitude from that of social instinct.

It has generally been thought that change of attitude is necessary before other behavioral changes can be made (Zainuddin, 1977).

Rishi (2003) emphasized that understanding attitudes is one of the central concerns in social life and that it is relatively crucial for bringing about the desired change in behavior.

The collective and personal acts of people are directed by their attitudes. Attitudes help to predict and control behavior, which is useful for implementing participation successfully.

Research by Kosecik\&Sagbas (2004), says that the attitude of citizens affects their participation and is an essential element to increase it.

Aspden and Brich (2005) have shown that there are a number of factors and issues affecting public attitudes to participation in local affairs and decision-making.

Their justifications consist of; the interest of citizens and their understanding of local government, citizens 'satisfaction with their involvement, citizens' trust in local government and its members, and previous experience with volunteer activities (Aspden and Brich, 2005). 
The guide on the culture of democracy (Council of Europe) set out attitudes that could influence the participation of citizens, the most important ones being chosen:

\section{The respect}

To have respect for someone is to treat him with respect and esteem in order not to harm him or harm him. The word "respect" comes from the Latin respectus, "respect", "consideration". Respect can be simply a mark of politeness, an agreed formula, but on the other hand, the feeling and the recognition that one has of the value as a person impose the respect of others.

At Kant, this term takes on a particular meaning. Respect does not come from feeling and sensitivity, but from the moral law erected by practical reason. his respect therefore becomes a moral obligation. Respect is an attitude towards someone or something (eg a person, belief, symbol, principle, practice, etc.) that is considered to be of some importance or a value or interest that guarantees positive consideration and esteem. On the contrary, it is an attitude of positive appreciation of

the dignity and the right of others to have their own references, beliefs, opinions or practices, while recognizing and accepting the differences between themselves and the other.

Respect for others, is therefore based on the acceptance of a principle of equality between men.We know that the other has the same rights as us, and the same duties.It is then a question of a positive consideration and esteem for others as equal human beings who share a common dignity and enjoy exactly the same rights and freedoms, regardless of their cultural background, beliefs, opinions, lifestyles or practices.

\section{The responsibility}

The term "responsibility" has several meanings, one of which is particularly relevant for effective participation, namely moral responsibility. It is a notion that refers the individual to his or herownactions ;Itisalso a person who is in charge of makingdecisions.

It comes into play when a person is required to act in a certain way and deserves praise or criticism for having acted or otherwise neglected to act in this way. The conditions necessary to consider that a person deserves such praise or criticism being that she is able to reflect on her actions, to formulate intentions as to how she will act and to carry out the chosen actions.

The responsibility of his actions thus requires:

- The adoption of a thoughtful and serious attitude towards his acts and their possible consequences ;

- Decision-making regarding the actions to be performed (which in some cases may 
consist of not performing any actions), given the circumstances ;

- Willingness to assume responsibility for the nature or consequences of one's own decisions and actions ;

- Willingness to act with courage when deemed necessary.

\section{Conclusion}

As we stated at the beginning, this article introduces the skills that people must acquire to participate effectively and live in peace with one another, on an equal footing, in democratic societies.According to literature and other research, having skills is one of the most important and effective factors of participation that play an important role in encouraging citizens to participate.

Based on the research of Guy Le Boterf, we have defined the concept of competence from the notion of "knowledge", these knowledge could be cognitive, technical and relational (knowledge, know-how and know-how to be), an attempt is done to classify them, and the table below summarizes the whole model set:

\section{Table $N^{\circ}$ 01: Competence Concept Analysis Model}

\begin{tabular}{|c|c|c|c|}
\hline Concept & dimensions & Sub-dimension & Indicators \\
\hline \multirow{9}{*}{$\begin{array}{l}\text { Competencie } \\
\mathrm{s}\end{array}$} & \multirow{3}{*}{ Knowledge } & & $\begin{array}{l}\text { Knowledge of } \\
\text { communication }\end{array}$ \\
\hline & & & $\begin{array}{l}\text { Knowledge of politics and } \\
\text { law }\end{array}$ \\
\hline & & & Knowledge of human rights \\
\hline & \multirow{4}{*}{ Know how to be } & \multirow[b]{2}{*}{ Values } & Equality \\
\hline & & & Freedom \\
\hline & & \multirow[b]{4}{*}{ Aptitudes } & Respect \\
\hline & & & Responsability \\
\hline & \multirow[b]{2}{*}{ Know how } & & Capacity of listening and \\
\hline & & & \begin{tabular}{|l|} 
Capacity for cooperation \\
\end{tabular} \\
\hline
\end{tabular}

Source : author, 2018

This competency analysis model that we presented in this work serves as a support and reference framework for future research in order to study the level of competence of residents in a participatoryprocess.

Our study provides only a partial treatment to this vast and complex question of the participation of the inhabitants. It would thus be necessary to make sure that the 
motivation and the ethics are very present among the inhabitants, so that it can be reflected on other actors, allowing the process of participation to be prolonged.

\section{References}

[1] Aristote, Les politiques, Traduction et présentation par Pierre Pellegrin, GFFlammarion, 1993 (en particulier le livre III).

[2] BARBOT (M.J) et CAMATARRI (G), 1999, autonomie et apprentissage,l'innovation dans la formation, Paris, PUF.

[3] Commission européenne - Enseigner et apprendre : vers la société cognitive.

[4] COULON (A), HAEUW (F), les compétences du formateur en FormationOuverte et A Distance, étude téléchargeable sur le site ALGORAhttp://www. algora.org

[5] DE MONTMOLLIN (M), 1984, l'intelligence de la tâche. Elémentsd'ergonomie cognitive, Berne, Peter Lang

[6] DE ROMAINVILLE (M), 1998, L'étudiant - apprenant - grilles de lecture pourl'enseignant universitaire, De Boeck.

[7] DELORS (J), 1999, Education : un trésor est caché dedans, Editions UNESCO

[8] Documentation Française, Paris, mai 2008, 157p.

[9] Forum Pédagogique, Savoir, oui ... mais encore ! FM. GERARD, X. ROGIERS, 1993, Concevoir et évaluer des manuels scolaires, Bruxelles de Boeck Université, mai 2000.

[10] Fritz Oser, Manuela Ullrich, Horst Biedermann (2000), " Jeunesse et citoyenneté : Expériences de participation et compétences individuelles », Département des sciences de l'éducation de l'université de Fribourg, Chaire de pédagogie et de psychopédagogie, Regina Mundi, rue Faucigny 2, CH-1700 Fribourg.

[11] Groupe de travail « référentiel » de la plate-forme « Métier du développement territorial », Référentiel de compétences, Cœur des métiers, UNADEL, septembre 2005, 30p.

[12] J.-C. Gay IUFM d'Auvergne-UBP, «Valeurs de la démocratie et valeurs de la république », CAVL 11 mai 2011, page 6.

[13] Katia GRENIER, « La participation des habitants : des compétences partagées entre les différents acteurs ? Etude à partir de projets de centres sociaux des Alpes-Maritimes »,Diplôme d'Etat d'Ingénierie Sociale Région PACA, soutenue en décembre 2009, Institut Régional de Travail Social PACA et Corse.

[14] KATZ R.L., Skills of an effective administrator, Harvard Business Review,Vol. $51,1974$.

[15] " La participation des citoyens et l'action publique », Centre d'analyse stratégique,

[16] « Le référentiel de compétences des professionnels du développement territorial », Les cahiers de développeur économique $n^{\circ} 8$, ARADEL, octobre 2005, $28 \mathrm{p}$. 
[17] LE BOTERF (G), 1995, De la compétence, essai sur un attracteur étrange, Paris, Editions d'organisations.

[18] LE BOTERF (G), 1997, compétence et navigation professionnelle, Paris,Editions d'organisation.

[19] LE BOTERF (G), 2000, construire les compétences individuelles et collectives, Paris, Editions d'organisations.

[20] MartynBarrett, " Compétences pour une culture de la démocratie, vivre ensemble sur un pied d'égalité dans des sociétés démocratiques et culturellement diverses », Éditions du Conseil de l'Europe F-67075 Strasbourg Cedex, Avril 2016, http://book.coe.int.

[21] MUTWIRI GIDEON KIMATHI, Factors influencing public participation in the county integrated development planning process "a case of county government of Meru", Master thesis, Nairobi university June 2016.

[22] Rotter, J. B. (1966). "Generalized expectancies for internal versus external control of reinforcement". PsychologicalMonographs: General \&Applied. 80 (1): 1-28. doi:10.1037/h0092976

[23] SAMURCAY (R) et PASTRE (P), 1995, Outiller les acteurs de la formationpour le développement des compétences ", in Education permanente $\mathrm{N}^{\circ} 123$

[24] Seyed Hamid Mohammadi, Sharifah NorazizanetNobaya Ahmad “Citizens' Attitude toward's Local Government and Citizen's Participation in Local Government", Journal of American Science, 2010;6(11):575-583, . (ISSN: 1545-1003). http://www.americanscience.org.

[25] Shalom H. schwartz, « Les valeurs de base de la personne : théorie, mesures et applications ", Revue française de sociologie2006/4 (Vol. 47), Pages : 320 ; http://www.cairn.info/revue-francaise-de-sociologie-1-2006-4-page929.html

[26] TREMBLAY $(\mathrm{N})$, les quatre compétences de l'autoformation, Les sciences del'Education 39 1-2,

[27] Zaïr KEDADOUCHE, " Rapport sur la participation des habitants dans les opérations de renouvellement urbain, à l'attention de Jean-Louis BORLO0», IGAS, Avril 2003, 20p. 